\title{
PUPUK KANDANG DIPERKAYA FOSFAT ALAM DALAM BENTUK GRANULAR DAN DIINOKULASI BIODEKOMPOSER UNTUK MENINGKATKAN NUTRISI JERAMI JAGUNG MANIS SEBAGAI HIJAUAN PAKAN LOKAL DI LAHAN KERING
}

\author{
Dwi Retno Lukiwati ${ }^{1}$, Endang Dwi Purbayanti ${ }^{1}$, dan Retno Iswarin Pujaningsih ${ }^{2}$ \\ 1. Jurusan Pertanian, Fakultas Peternakan dan Pertanian, Universitas Diponegoro \\ 2. Jurusan Peternakan, Fakultas Peternakan dan Pertanian, Universitas Diponegoro \\ Telp./Faks: 024 7474750, Email: drlukiwati_07@yahoo.com
}

\begin{abstract}
ABSTRAK
Pupuk kandang diperkaya fosfat alam (FA) dan di inokulasi biodekomposer bermanfaat untuk memperbaiki kesuburan lahan kering. Tujuan penelitian untuk mengetahui pengaruh beberapa macam pupuk kandang diperkaya FA (pukan) dalam bentuk granular dan di inokulasi biodekomposer terhadap nutrisi jerami jagung manis sebagai hijauan pakan lokal untuk ruminansia. Penelitian lapang menggunakan rancangan acak lengkap dengan 7 perlakuan dan 4 ulangan pada tanah vertisol. Dosis unsur hara $\mathrm{P}(\mathrm{FA}), \mathrm{N}$ (urea), dan $\mathrm{K}(\mathrm{KCl})$ masingmasing $66 \mathrm{~kg} / \mathrm{ha}, 200 \mathrm{~kg} / \mathrm{ha}$ dan $125 \mathrm{~kg} \mathrm{~K} / \mathrm{ha}$. Dosis pukan $30 \mathrm{t} / \mathrm{ha}$ dan semua diperkaya FA. Perlakuan yang diberikan adalah To (pukan), T1 (pukan+EM4), T2 (pukan+starTmik), T3 (pukan+stardec), T4 (pukan granular+EM4), T5 (pukan granular+starTmik), T6 (pukan granular+stardec). Panen jagung manis pada umur 70 hari setelah tanam, dan jerami dipotong untuk mendapatkan data kadar protein kasar (PK), fosfor (P) dan kalsium (Ca). Hasil penelitian menunjukkan bahwa perlakuan yang diberikan nyata berpengaruh terhadap nutrisi jerami. Hasil uji DMRT menunjukkan bahwa beberapa macam pupuk kandang diperkaya FA (pukan) menghasilkan kadar PK, P dan Ca jerami jagung manis tidak nyata berbeda. Dapat disimpulkan bahwa pukan diperkaya FA dengan atau tanpa biodekomposer dalam bentuk granular atau non-granular mempunyai kemampuan yang sama dalam menghasilkan kadar PK, P dan Ca jerami jagung manis.
\end{abstract}

Kata kunci: biodekomposer, fosfor, jerami, pupuk kandang, Zea mays saccharata

\begin{abstract}
Manure enriched with rock phosphate (RP) and inoculated with biodecomposer very important to improve the dry land fertility. The objective of the research was to investigate the influence of some kind of manure enriched with RP in granular form and biodecomposer inoculated on sweet corn (Zea mays saccharata) stover nutrient as local forage feed for ruminant. A field experiment of completely randomized design with 7 treatments and four replicates was conducted on vertisol soil. Level of $\mathrm{P}(\mathrm{RP}), \mathrm{N}$ (urea) and $\mathrm{K}(\mathrm{KCl})$ fertilizers was 66 $\mathrm{kg} \mathrm{P} / \mathrm{ha}, 200 \mathrm{~kg} \mathrm{~N} / \mathrm{ha}$, and $125 \mathrm{~kg} \mathrm{~K} / \mathrm{ha}$, respectively. All of manure application at $30 \mathrm{t} / \mathrm{ha}$, and enriched with RP. The treatments were To (manure), T1 (manure+EM4), T2 (manure+starTmik), T3 (manure+stardec), T4 (manure granular+EM4), T5 (manure granular+starTmik), and T6 (manure granular+stardec). The sweet corn was harvested at 70 days after planting, the stover was cut and measured for crude protein (CP), phosphorus $(\mathrm{P})$, and calcium $(\mathrm{Ca})$ concentration. The result showed that the treatment significantly affected to the nutritive value of sweet corn stover. The result of DMRT showed that effect of some kind of manure enriched with $\mathrm{RP}$ was not significantly different on $\mathrm{CP}, \mathrm{P}$, and Ca concentration of sweet corn stover. Conclusion, manure enriched by RP with or without biodecomposer, in granular or non-granular form, resulted in similar on $\mathrm{CP}, \mathrm{P}$, and $\mathrm{Ca}$ concentration of sweet corn stover.
\end{abstract}

Keywords: biodecomposer, manure, phosphorus, stover, Zea mays saccharata.

\section{PENDAHULUAN}

Sistem integrasi tanaman-ternak (SITT) dicirikan oleh keterkaitan antara tanaman pertanian dengan ternak. Hasil tanaman pertanian misalnya jagung manis untuk pangan, jerami sebagai pakan sedangkan limbah usaha peternakan (feses, urine, sisa pakan) dimanfaatkan sebagai pupuk kandang (pukan). Tanah vertisol pada umumnya termasuk defisien unsur hara fosfor, dan merupakan salah satu faktor pembatas pertumbuhan jagung. Keadaan tersebut selama ini diatasi dengan pemupukan SP-36 (Lukiwati, 2002; Kasno et al., 2006). Pupuk SP-36 merupakan hasil reaksi antara batuan fosfat (BP) atau disebut juga sebagai fosfat alam (FA) dengan asam sulfat sehingga mudah larut dalam air dan cepat tersedia bagi akar tanaman. Oleh karena itu produksi tanaman jagung lebih tinggi dengan pemupukan SP-36 dibanding FA yang bersifat lambat tersedia karena tidak larut dalam air (Lukiwati, 2002). 
Mahalnya harga pupuk SP (36\% P2O5) bahkan langka ketika dibutuhkan, menyebabkan perlunya dicari alternatif lain yaitu dengan memanfaatkan pupuk $\mathrm{P}$ alam misalnya batuan fosfat atau fosfat alam (27\% P2O5). Pupuk FA berasal dari batuan fosfat digiling halus, mengandung trikalsium fosfat atau Ca3 (PO4)2 (Young et al. 1985). Pupuk FA (1227\% P2O5) tidak larut dalam air, tetapi larut dalam asam (Dierolf et al. 2001; Lukiwati et al. 2001). Pupuk FA lebih sesuai diterapkan pada tanah masam $(\mathrm{pH}$ $<5,5$ ) dengan dosis $1-1,5$ ton FA/ha atau $300-450 \mathrm{~kg}$ $\mathrm{P} 2 \mathrm{O} 5 /$ ha (Dierolf et al. 2001). Pendapat yang sama telah dinyatakan oleh Kerridge dan Ratcliff (1982) dan Young et al. (1985) bahwa pupuk FA lebih sesuai digunakan pada tanah-tanah masam. Dosis pupuk FA menurut Sharma et al. (2001) dengan sekali pemberian sebanyak $500 \mathrm{~kg} \mathrm{P2O} /$ ha untuk masa tanam 5 tahun, menghasilkan produksi jagung rata-rata meningkat 50 \% lebih tinggi dibanding tanpa pemupukan P. Nassir (2001) juga melaporkan bahwa satu kali pemberian pupuk FA dengan dosis 80-36o kg $\mathrm{P}_{2} \mathrm{O}_{5} / \mathrm{ha}$, dapat meningkatkan produksi jagung setara atau bahkan lebih tinggi dibanding pemupukan SP. Lukiwati (2002) menyatakan bahwa efisiensi pemupukan $P$ untuk produksi biji tertinggi dicapai pada dosis 66 $\mathrm{kg} \mathrm{P} / \mathrm{ha}$ atau $150 \mathrm{~kg} \mathrm{P} 2 \mathrm{O} 5 / \mathrm{ha}$.

Limbah usaha peternakan sapi potong selain feses dan urine juga sisa-sisa pakan dapat dimanfaatkan sebagai pupuk kandang (pukan) melalui proses dekomposisi, agar rasio $\mathrm{C} / \mathrm{N}$ dibawah 20, dan dapat dipercepat dengan memanfaatkan mikroba dekomposer (Edesi et al., 2012). Bakteri dan fungi telah banyak dimanfaatkan sebagai dekomposer antara lain Trichoderma sp. dan Aspergilus. Mikroba perombak bahan organik sebagai aktivator biologik, tumbuh alami atau sengaja di inokulasikan dan telah tersedia secara komersial dengan berbagai nama antara lain EM-4, stardec, dan starTmik. Feses sapi dapat mempercepat proses dekomposisi bahan organik, karena dalam feses juga mengandung bakteri atau cendawan dekomposer (Saraswati dan Sumarno, 2008). Pupuk kandang dapat meningkatkan populasi bakteri sebanyak 0,02\% (Azotobacter) dan 0,46\% (Azospirillum) dalam tanah (Mujiyati dan Supriyadi, 2009). Genus fungi yang terdapat dalam hasil dekomposisi campuran feses segar dan batuan fosfat adalah Chytridium sp., Aspergillus sp., Rhizopus sp. dan Fusarium sp (Nugroho et al., 2013). Aplikasi pupuk kandang dapat meningkatkan kandungan N total tanah (Mujiyati dan Supriyadi, 2009). Pukan sapi selain mengandung unsur hara $\mathrm{N}$, P dan $\mathrm{K}$ masing-masing 0,55 ; 0,12 dan $0,30 \%$ (Soelaeman, 2008), juga asam-asam humat dan fulfat berperan dalam meningkatkan kelarutan pupuk FA Pupuk kandang berperan dalam meningkatkan kesuburan fisik tanah karena mampu meingkatkan agregat ruang pori, ketersediaan air dan aerasi tanah (Jamariah dan Sulichantini, 2004). Dosis aplikasi pukan berkaitan dengan jenis tanaman yang dipupuk., misalnya untuk tanaman jagung di lahan kering antara 1-2 ton/ha (Hartatik dan Widowati, 2006). Produksi padi dipupuk pukan dengan inokulasi dekomposer tidak berbeda dibanding tanpa dekomposer, masingmasing 2,25 t/ha dibanding 2,19 ton/ ha. Aplikasi dekomposer nyata berpengaruh terhadap kandungan $P$ daun (Nurrahma dan Melati, 2012).

Berdasarkan uraian tersebut diatas maka penelitian telah dilakukan untuk mengetahui pengaruh beberapa jenis pukan diperkaya fosfat alam terhadap kadar protein kasar (PK), kalsium (Ca) dan fosfor (P) jerami jagung manis pada tanah vertisol.

\section{MATERI DAN METODE}

Penelitian telah dilaksanakan di kebun percobaan pada jenis tanah vertisol selama 70 hari. Materi yang digunakan adalah benih jagung manis (Zea mays saccharata), pupuk dasar (urea dan $\mathrm{KCl}$ ) dan pupuk kandang diperkaya fosfat alam (pukan) sebanyak 7 macam. Pembuatan 7 macam pukan dilakukan dengan penambahan fosfat alam (batuan fosfat digiling halus) setara $66 \mathrm{~kg} \mathrm{P} / \mathrm{ha}\left(150 \mathrm{~kg} \mathrm{P} 2 \mathrm{O}_{5} /\right.$ ha) pada waktu proses dekomposisi pukan $30 \mathrm{t} / \mathrm{ha}$. Dekomposer EM-4, StarTmik dan Stardec digunakan untuk mempercepat proses dekomposisi pukan sesuai perlakuan masing-masing. Analisis kimia pukan dan tanah dilakukan sebelum penelitian dilaksanakan. Perlakuan pemupukan yang diberikan adalah To (pukan), T1 (pukan+EM4), T2 (pukan+starTmik), $\mathrm{T}_{3}$ (pupuk+stardec), $\mathrm{T}_{4}$ (pukan granular+EM4), T5 (pukan granular+starTmik), dan T6 (pukan granular+stardec).

Rancangan percobaan yang digunakan adalah rancangan acak lengkap dengan 7 perlakuan dan 4 kali ulangan sehingga terdapat 28 petak percobaan. Semua petak diberi pupuk dasar urea $200 \mathrm{~kg} \mathrm{~N} / \mathrm{ha}$ dan $\mathrm{KCl} 125 \mathrm{~kg} \mathrm{~K}$ (150 kg K2O/ha) sesuai rekomendasi Lukiwati et al. (2010).

\section{Pelaksanaan Penelitian}

Media tanam disiapkan sebanyak 28 petak ukuran $3 \times 2,5 \mathrm{~m} /$ petak. Dilanjutkan pembuatan 7 macam pupuk kandang diperkaya fosfat alam, dan yang 3 macam masing-masing diberi accelerator EM4, starTmik dan stardec, sedangkan 3 macam lainnya juga diberi accelerator dan dibuat dalam bentuk granular. Tujuh macam pukan perlakuan diberikan seminggu sebelum tanam, sedangkan pupuk dasar (urea dan $\mathrm{KCl}$ ) bersamaan waktu tanam. Penanaman 2 benih jagung manis tiap lubang tanam, dengan jarak tanam $40 \times 30 \mathrm{~cm}$ sehingga terdapat 36 lubang tanam tiap petak. Perawatan tanaman dilakukan meliputi penyiraman (ketika diperlukan), pengendalian hama dan gulma serta pendangiran. Pengendalian hama dilakukan dengan pemberian insektisida furadan ketika mulai muncul _contong' daun.

Panen jagung manis pada umur 70 hari dan dilakukan pemotongan jerami untuk di analisis kadar protein kasar (\% N x 6,25), kadar Ca dan P jerami menurut Islam et al. (1992). Data hasil penelitian tersebut di analisis ragam untuk mengetahui pengaruh 
perlakuan, dan dilanjutkan uji wilayah ganda Duncan untuk mengetahui perbedaan antar perlakuan terhadap parameter yang diamati.

\section{HASIL DAN PEMBAHASAN}

\section{Kadar Protein Kasar Jerami Jagung Manis}

Hasil analisis ragam menunjukkan bahwa perlakuan yang diberikan berpengaruh nyata terhadap kadar protein kasar jerami jagung manis (Tabel 1). Data Tabel 1 menunjukkan bahwa kadar PK jerami jagung manis dipengaruhi oleh perlakuan berbagai jenis pukan. Hasil uji DMRT menunjukkan bahwa pukan (To) menghasilkan kadar PK jerami tidak berbeda dibanding pukan dengan inokulasi biodekomposer (T1, T2, T3). Begitu juga kadar PK jerami dengan pemupukan pukan (To) tidak berbeda dibanding pukan granular+biodekomposer ( $\left.\mathrm{T}_{4}, \mathrm{~T}_{5}, \mathrm{~T} 6\right)$. Pukan nongranular ( $\left.\mathrm{T} 1, \mathrm{~T} 2, \mathrm{~T}_{3}\right)$ dan pukan granular $\left(\mathrm{T}_{4}, \mathrm{~T}_{5}\right.$, T6) tidak berbeda kemampuannya dalam menghasilkan kadar PK jerami jagung. Hal ini disebabkan karena dalam pupuk kandang sudah mengandung mikroba dekomposer alami yang aktif dalam proses dekomposisi (Saraswati dan Sumarno, 2008), sehingga ketika pukan di inokulasi dengan berbagai dekomposer serta dibentuk menjadi pukan granular maupun nongranular tidak nyata pengaruhnya terhadap kadar PK jerami jagung.

Tabel 1. Kadar protein kasar, kalsium dan fosfor jerami jagung manis dengan pemupukan beberapa macam pupuk kandang

\begin{tabular}{lccc}
\hline \multicolumn{1}{c}{ Perlakuan pemupukan } & $\begin{array}{c}\text { Kadar PK } \\
(\%)\end{array}$ & $\begin{array}{c}\text { Kadar Ca } \\
(\%)\end{array}$ & $\begin{array}{c}\text { Kadar P } \\
(\%)\end{array}$ \\
\hline T0. Pukan & $5,70^{\mathrm{b}}$ & $0,19^{\mathrm{ab}}$ & $0,56^{\mathrm{a}^{*}}$ \\
T1. Pukan+EM4 & $6,69^{\mathrm{ab}}$ & $0,30^{\mathrm{a}}$ & $0,48^{\mathrm{ab}}$ \\
T2. Pukan+StarTmik & $6,84^{\mathrm{ab}}$ & $0,18^{\mathrm{ab}}$ & $0,51^{\mathrm{ab}}$ \\
T3. Pukan+Stardec & $6,74^{\mathrm{ab}}$ & $0,17^{\mathrm{b}}$ & $0,55^{\mathrm{a}}$ \\
T4. Pukan granular+EM4 & $7,11^{\mathrm{a}}$ & $0,20^{\mathrm{ab}}$ & $0,47^{\mathrm{ab}}$ \\
T5. Pukan granular+StarTmik & $5,70^{\mathrm{b}}$ & $0,24^{\mathrm{ab}}$ & $0,43^{\mathrm{ab}}$ \\
T6. Pukan granular+Stardec & $6,44^{\mathrm{ab}}$ & $0,25^{\mathrm{ab}}$ & $0,39^{\mathrm{b}}$ \\
\hline
\end{tabular}

* Superskrip berbeda pada kolom yang sama, menunjukkan berbeda nyata pada taraf $5 \%$ dengan uji DMRT

Disamping itu, hasil analisis kandungan unsur hara $\mathrm{N}, \mathrm{P}$ dan K berbagai macam pukan tersebut cenderung tidak berbeda (data tidak ditampilkan). Namun demikian pukan granular+EM4 (T4) menghasilkan kadar PK jerami nyata lebih tinggi dibanding pukan. Hal ini disebabkan karena EM4 mengandung mikroba dekomposer yang mampu meningkatkan ketersediaan fosfat dan unsur hara lainnya, serta bentuk granular dapat menekan terjadinya pencucian unsur hara. Oleh karena itu secara umum pukan mampu menghasilkan kadar PK jerami jagung manis tidak berbeda dibanding perlakuan pemupukan lainnya.

\section{Kadar Kalsium Jerami Jagung Manis}

Hasil analisis ragam menunjukkan bahwa perlakuan yang diberikan berpengaruh nyata terhadap kadar Ca jerami jagung manis. Data Tabel 1 menunjukkan bahwa pukan (Po) menghasilkan kadar Ca berbeda tidak nyata dibanding pukan+biodekomposer (T1, T2, T3), demikian pula terhadap pukan granular+biodekomposer $\left(\mathrm{T}_{4}\right.$, T5, T6). Pukan non-granular (T1, T2, T3) dan pukan granular $\left(\mathrm{T}_{4}, \mathrm{~T} 5, \mathrm{~T} 6\right)$ tidak berbeda kemampuannya dalam menghasilkan kadar Ca jerami jagung. Dengan demikian, berbagai macam pukan tersebut mempunyai kemampuan yang sama dalam menghasilkan kadar Ca jerami jagung manis. Hal ini disebabkan karena kandungan unsur hara N, P dan $\mathrm{K}$ berbagai macam pukan tersebut cenderung tidak berbeda (data tidak ditampilkan). Pupuk kandang sudah mengandung mikroba dekomposer alami yang aktif dalam proses dekomposisi (Saraswati dan Sumarno, 2008), sehingga diberi maupun tanpa inokulasi mikroba dekomposer tidak nyata pengaruhnya terhadap kadar Ca jerami jagung. Pupuk kandang berperan dalam meningkatkan kesuburan fisik tanah karena meningkatkan plastisitas, agregat pori tanah, ketersediaan air dan aerasi tanah (Jamariah dan Sulichantini, 2004) dan mempunyai kemampuan sama dalam meningkatkan pertumbuhan dan produksi tanaman (Nurrahma dan Melati, 2012).

\section{Kadar Fosfor Jerami Jagung Manis}

Hasil analisis ragam menunjukkan bahwa perlakuan yang diberikan berpengaruh nyata terhadap kadar $P$ jerami jagung manis. Hasil uji DMRT tercantum pada Tabel 1, menunjukkan bahwa pukan (To) menghasilkan kadar $\mathrm{P}$ berbeda tidak nyata dibanding pukan+biodekomposer ( $\mathrm{T} 1, \mathrm{~T} 2, \mathrm{~T} 3)$, demikian pula terhadap pukan granular+biodekomposer ( $\left.\mathrm{T}_{4}, \mathrm{~T}_{5}, \mathrm{~T} 6\right)$. Dengan demikian, pukan tanpa inokulasi mikroba dekomposer pun (To) mampu memberikan hasil (kadar P jerami) setara dengan pukan yang di inokulasi, dalam bentuk pukan granular maupun nongranular. Pukan non-granular ( $11, \mathrm{~T}_{2}, \mathrm{~T} 3$ ) dan pukan granular ( $\left.\mathrm{T}_{4}, \mathrm{~T} 5, \mathrm{~T} 6\right)$ tidak berbeda kemampuannya dalam menghasilkan kadar $\mathrm{P}$ jerami jagung. Hal ini disebabkan karena pupuk kandang sudah mengandung mikroba dekomposer alami yang aktif dalam proses dekomposisi (Saraswati dan Sumarno, 2008), sehingga ketika di inokulasi mikroba dekomposer tidak nyata pengaruhnya terhadap kadar P jerami jagung. Perlakuan berbagai macam pukan memberikan pengaruh yang sama dalam menghasilkan kadar $P$ jerami jagung manis, kecuali pukan granular+stardec (T6) nyata lebih rendah dbanding pukan (To). Diduga biodekomposer stardec pada perlakuan T6 dalam pukan granular tidak mampu meningkatkan ketersediaan fosfat seperti pada perlakuan pemupukan lainnya. Meskipun pukan non-granular (T1, T2) dan pukan granular ( $\left.\mathrm{T}_{4}, \mathrm{~T}_{5}\right)$ tidak berbeda kemampuannya dalam menghasilkan kadar P jerami jagung, namun T6 (pukan granular+stardec) menghasilkan kadar P jerami nyata lebih rendah dibanding T3 (pukan+stardec). Diduga pukan granular+stradec tidak mampu meningkatkan ketersediaan fosfat setara dengan pukan+stardec. 


\section{SIMPULAN}

Berbagai macam pupuk kandang diperkaya fosfat alam mempunyai kemampuan sama dalam menghasilkan kadar protein kasar, kalsium dan fosfor jerami jagung manis. Pupuk kandang diperkaya fosfat alam tanpa inokulasi biodekomposer menghasilkan nutrisi jerami jagung manis setara dengan pukan di inokulasi mikroba dekomposer dalam bentuk granular maupun non-granular. Pukan granular maupun nongranular mempunyai kemampuan tidak berbeda dalam menghasilkan nutrisi jerami jagung.

\section{UCAPAN TERIMA KASIH}

Penelitian ini dibiayai oleh DIPA UNDIP Semarang, No: 0363/023-04.2/XIII/2010 tanggal 31 Desember 2009, sesuai dengan SPK Penelitian Multi Tahun Hibah Bersaing T.A. 2013, No: 154a-11/UN7.5/ PG/2013, tanggal 15 Februari 2013. Juga dibantu oleh Kelompok Tani _Sumber Subur' Kabupaten Sragen (Ketua: Bpk. Sugimin) dalam pelaksanaan di lapang. Untuk semua itu, Tim Peneliti mengucapkan terima kasih.

\section{DAFTAR PUSTAKA}

Dierolf T., T. Fairhurst and E. Mutert. 2001. Soil Fertility Kit. A toolkit for acid, upland soil fertility management in Southeast Asia. First edition. Printed by Oxford Graphic Printers. 149 p.

Edesi, L., M. Jarvan, M. Noormeths, E. Lauringson, A. Adamson, and E.Akk. 2012. The importance of soil cattle manure application on soil microorganism inorganic and conventional cultivation. Acta Agric. Scandinavida. Section B - Soil \& Plant Sci. 62(7): 583-594.

Hartatik, W. and L.R. Widowati. 2006. Pupuk Kandang. Dalam: Pupuk Organik dan Pupuk Hayati. Balai Besar Litbang Sumberdaya Lahan Pertanian, Badan Penelitian dan Pengembangan Pertanian. Bogor.

Islam AKMS., G. Kerven and Oweczkin. 1992. Methods of Plant Analysis. ACIAR 8904 IBSRAM QC.

Jamariah dan E.D. Sulichantini. 2004. Pengaruh pemberian pupuk kandang ayam dan media tanam terhadap pertumbuhan dan hasil tanaman bawang sabrang (Eleutherine americana L.). Budidaya Pertanian, 10(2): 88-93.

Kasno A., D. Setyorini and E. Tuberkih. 2006. Pengaruh pemupukan fosfat terhadap produktivitas tanah Inceptisol dan Ultisol. Jurnal Ilmu-Ilmu Pertanian Indonesia. 8(2):9198.

Kerridge, P.C. and D. Ratcliff. 1982. Comparative growth of four tropical pasture legumes and guinea grass with different phosphorus sources. Trop. Grassld. 16(1): 33-40.

Lukiwati D.R., R. Ekowati dan Karno. 2001. Produksi bahan kering dan kadar protein kasar rumput setaria gajah dengan pemupukan N dan P. Abstr. p. 167. Seminar Nasional Pengembangan Peternakan Berbasis Sumberdaya Lokal. Fakultas Peternakan IPB, Bogor. 8-9 Agustus.

Lukiwati, D.R. 2002. Effect of rock phosphate and superphosphate fertilizer on the productivity of maize var. Bisma. In: Proc.of International Workshop Food Security in NutrientStressed Environments: Exploiting Plant's Genetic Capabilities. International Crops Research Institute for Semi-Arid Tropics (ICRISAT) Patancheru, India, 27. Kluwer Academic Publishers. Netherlands. p.183-187.

Lukiwati, D.R., Surahmanto and B.A. Kristanto. 2010. Production and nutrient uptake improvement of sweet corn by rock phosphate combined with manure and mycorrhiza inoculation. Abstr.p.8o. International Conference on Balanced Nutrient Management for Tropical Agriculture. Kuantan, Pahang. Malaysia, 12-16 April.

Mujiyati dan Supriyadi. 2009. Pengaruh pupuk kandang dan NPK terhadap populasi bakteri Azotobacter dan Azospirillum dalam tanah pada budidaya cabai (Capsicum annum). Bioteknologi, 6(2): 63-69.

Nassir, A. 2001. IMPHOS experience on direct application of phosphate rock in Asia. In: Proc.of an International Meeting - Direct Application of Phosphate Rock and Related Appropriate Technology - Latest Developments and Practical Experiences. Kuala Lumpur. 16-20 July. pp. 110-122. Nugroho, S.G., Dermiyati, J. Lumbanraja, S. Triyono, H. Ismono, M.K. Ningsih dan F.Y. Saputra. 2013. Inoculation effect of N2-Fixer and P-solubilizer into a mixture of fresh manure and phosphate rock formulated as organonitrofos fertilizer on bacterial and fungal populations. J. Trop. Soils. 18(1): $75-80$.

Nurrahma, A.H.I. and M. Melati. 2012. The influence of fertilizer type and decomposer on organic rice growth and yield. J. Agrohorti, 1(1): 1

Saraswati, R. dan Sumarno. 2008. Pemanfaatan mikroba penyubur tanah. Iptek Tanaman Pangan. 3(1): 1-58. Sharma, P.K., S.K. Bhardwaj and H.L.

Sharma. 2001. Long-term a studies on agronomic effectiveness of African and Indian phosphate rocks in relaton to productivity of maize and wheat crops in mountain acid soils of Western Himalayas (India). In: Proc.of International Meeting - Direct Application of Phosphate Rock and Related Appropriate Technology-Latest Developments and Practical Experiences. IFDC/MSSS/ESEAP. Kuala Lumpur, Malaysia. 322-328.

Soelaeman, Y. 2008. Efektivivtas pupuk kandang dalam meningkatkan ketersediaan fosfat, pertumbuhan dan hasil padi dan jagung pada lahan kering masam. J. Tanah Trop. 13(1): 41-47.

Young, R.D., D.G. Westfallm and G.W. Colliver. 1985. Production, Marketing, and Use of Phosphorus Fertilizers. In: O.P. Engestad (Ed.). Fertilizer Technology and Use. Third Ed. Published by Soil Soc.of Am., Inc. Madison, Wisconsin. 